\title{
Systematic Reform of Concrete Structure Teaching Considering the Characteristics of Students
}

\author{
Liu Yan ${ }^{1, a}$, Zou Xiaojin ${ }^{2, b}$ \\ ${ }^{1}$ School of Civil Engineering, Yangzhou University, Yangzhou, P.R.C \\ ${ }^{2}$ School of Civil Engineering, Yangzhou University, Yangzhou, P.R.C \\ aliuyan@yzu.edu.cn, byzdxzxj@163.com
}

Keywords: Characteristics of students, concrete structure, system reform

\begin{abstract}
Concrete structure is one of the key courses of civil engineering major. Comparing with other courses in this major, the contents of concrete structure have a typical characteristic of emphasizing both theory and practice, so the teaching and learning of this course are difficult. Based on years of teaching practice of concrete structure, the author tries to rearrange teaching contents according to the cognitive characteristics of students. The new teaching process generally follows the order of whole concepts of structures, then design elements as well as detailed configuration, and finally structures design. The teaching practices show the new process which makes the content more quickly and accurately accepted by students.
\end{abstract}

\section{The status of concrete structure course}

Concrete structure course is one of the major core courses of civil engineering specialty, and the first professional foundation course students meet. For civil engineering major, various universities attach great importance to concrete structure course teaching. Since early 1980's, every two year once China Civil Engineering Society Education Work Committee's Seminars on Concrete Structure Course has held 13 times, which fully shows the status and importance of the course in the profession.

How to combine the cognitive characteristics of students, develop concrete structure teaching, let the students understand the basic theory of concrete structure knowledge correctly, and combine with the subsequent structural design, whether for teaching or learning, is a difficult problem. Current universities and colleges concrete structure teaching is basically in accordance with the order of "component +structure", namely first teach the basic component design theory, then structure design knowledge. Based on years of concrete structure teaching, the author made systematic reform of teaching content, organized the content in accordance with "structure component after structure system, and then structure design (structure)", namely first teach building structure system knowledge, let the students set up a complete system of building structure knowledge, master structure arrangement principles and requirements, and then study the design theory of concrete structures. This can make more close relation between architectural structure system, basic components, and structural requirements to facilitate students' learning and understanding.

\section{Civil engineering students' cognitive characteristics}

While civil engineering colleges and universities make training plan formulation for four-year undergraduates, generally concrete structure course teaching is in second semester in the third year and first semester in the fourth year. The course is different from many basic courses of strict scientific and logical system. Students may feel concrete structure course content more difficult because it is multifarious with many symbols, formulas, and structural requirements.

Teachers generally are not very much concerned about grade three civil specialized students. After more than two years of time in school, how much do they know about building structure? We made a questionnaire survey about the basic problems concerning building structure on first and 
second grade civil engineering major students. It is found that students more or less have some basic understanding about daily living and all kinds of buildings, such as application material, structure, etc. Together with more than two years' preliminary study at the school about civil engineering related courses and a series of major related visit, internship, and lectures, students have some hazy understanding and superficial understanding about building structure system, so they specially want to know something about structure and layout. In concrete structure course teaching, students' cognitive characteristics are taken as the breakthrough point. Change the teaching of concrete structure from the traditional "component + structure" to "first structural system, then structural components, and structure design (structure)" teaching order, and let students better grasp the knowledge of structures, and grasp and study well concrete structure course.

\section{The analysis of current concrete structure teaching material}

Teaching materials and teaching of concrete structure course have the following several shortcomings:

First, current concrete structure teaching order is bad for students' establishing of the complete structure system concept. Current civil engineering colleges and universities have the teaching procedure of concrete structure course like basic components, floor system, high-level. Such teaching order makes students master single knowledge point, but cannot form the overall structure with these components, and it is difficult to understand the whole concept of the structure.

The second is that curriculum sequence is not in conformity with the current specification requirements. The concrete course structure adopts "component + structure" teaching order, which cannot testify "Concrete Structure Design Code" implemented from the beginning in July 2011. When preparing revised "Specification", structure scheme, continuous collapse prevention and design principles of existing structures and related structures conceptual design is added to the first part of "basic design rules". The author thinks that, part of the new specification needs adjustment, embodies the importance of overall structure concept, and it also reflects the "structure components after structure system, then structure design (structure)".

The third is that it has no organic combination with structure seismic design content. Since Wenchuan big earthquake in 2008, our country revised concrete design specification and seismic design code. Now domestic seismic fortification should be considered for all the city buildings, and seismic design of the building is mentioned a new level, so in front of the interpretation of structure arrangement, the basic concept of the seismic structure should be introduced, such as the classification and the standard of building seismic resistance, earthquake effects and ground and foundation, such as favorable housing location should be chosen as far as possible, avoiding bad location and dangerous areas. Teaching arrangement should combine with the destruction of all kinds of building structure system form under the action of earthquake, emphasize the effects of structure space skeleton arrangement principles and partition wall's effect on structure plane stiffness distribution, etc., and current concrete structure teaching material does not take into account the content of building structures seismic design.

\section{Systematic reform's main content of concrete structure teaching}

Based on the cognitive features of civil engineering students, in Higher Institutions Learning Civil Engineering Undergraduate Guidance Professional Norms requirements framework, the existing concrete structure course teaching order and teaching material content should be reorganized, and integration, in order to facilitate students' learning, better understanding and grasp the basic principle, method and related knowledge of concrete structure course. After integration, the concrete structure teaching material and reasonable teaching sequence are shown in the Figure below:

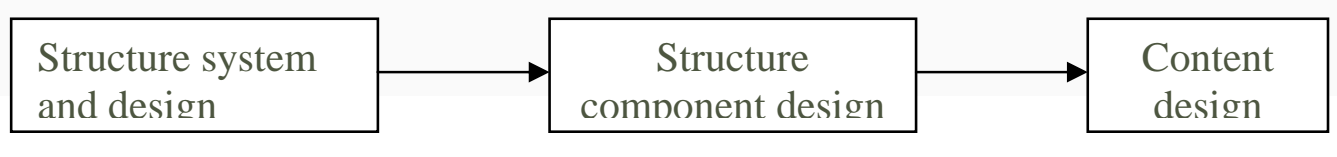


In the process of teaching, concrete structure teaching material can base on this major students' existing basic building knowledge and seismic knowledge, emphasizes the concept of structure system, structure classification, structure selection and arrangement principle to let the student have a whole structure understanding of daily life building; Second, based on the introduction of material properties of concrete structure, according to component form, component and mechanical test, design method, teach mechanical characteristics and function of the components like beam, plate, column, and put stress on components design; Finally, teach structure design, emphasize that the whole structure is on the basis of structural concept design, which is composed of effective connection structures. While teaching component design and structure design, introduce the corresponding moderate request of concrete structure specifically, and introduce and emphasize the reason and importance of structure knowledge. Through the above links, gradually develop students' attention and strictly abide by the norms of consciousness and habits.

\section{A. Pay attention to structure selection and arrangement, and strengthen building structure concept design knowledge}

In terms of concept structure design, let students make structure arrangement through determining structure scheme, gradually master building space form and the characteristics of various structure scheme and structure system, then make comprehensive consideration about the structure of earthquake knowledge, structure system layout principles and so on. In the structure concept design teaching, we should strengthen the following aspects:

(1) Strengthen structure system is the basis of ensuring seismic performance of buildings. In the structure and arrangement teaching, combine the basic concept of structural seismic gradually; let the students set up relatively complete system of structure and layout through the study of this part.

(2) Strengthen the training of discriminant structure rationality. Let the students compare analysis on rationality of structure system through the analysis of force and deformation of various engineering examples, such as the concentration stress and uniform force of components; single span, structure and multi span, simple support, continuous structure; structure space and plane role; structure rigid connection and hinged connection; statically determinate and statically indeterminate structure system; force simple structure and force twists and turns. By these analyses, the concept of reasonable structural system is formed.

(3) The concept of force. In structure system and arrangement teaching, it is appropriate to take several classes mainly introduce the concept of structural load and load transfer. Among them, the weight concept of the structure is especially emphasized to let the students know the main source of vertical load weight (about 85\% above) of the building is not only from load weight, and the earthquake action of horizontal load is directly related. Let students understand the reduction of building load weight can not only reduce the stress of the structure and the amount of construction material, at the same time it can reduce the cost of construction.

(4) Structure components design can also be introduced during the arrangement of knowledge structure, such as using frame structure, according to "depth-span ratio", "aspect ratio", "axial compression ratio" and the section size of frame column and beam. They can all be calculated and determined.

\section{B. Pay attention to the interpretation of structure design and construct knowledge}

Focus on various components' design and calculation. Change the past teaching of mechanical properties of different component to the teaching of basic building blocks (such as beam, slab, column, wall and foundation, etc.) respectively of the structure system. The benefits are that it can strengthen students' understanding of structural concept design and the role of various components in whole structural system, and make students better understand the complete structure of system and relationship between the structures.

Construction measures teaching should let students understand the role and importance of construction measures form the good habit of pay attention to comply with structural requirements. Especially through structural measures, let students further understand strong shear weak bending, strong column weak beam, and strong node weak component design idea. In teaching, this part of knowledge is to let the students' self-study and class discussions. For some of the content, such as 
beam longitudinal stress reinforced bending and spacing; stirrup diameter, number of limbs, spacing, etc., require students grouping and to make models, which not only cultivates students' practical ability, and deepens their understanding of structure of knowledge.

\section{Structure design knowledge learning}

The main content of structure design teaching is to integrate various aspects of knowledge, especially the combination of structure system conceptual design content and design structures, and structural mechanics knowledge. According to concrete single layer, multilayer structure, and high-rise structure design, introduce the classification of knowledge structure, and appropriately introduce some structure design software, such as PKPM, and explorer. Let the students form good structure concept, and basically grasp the knowledge of concrete structure through the study of this part.

\section{Full application of multimedia technology and case teaching method}

In concrete structure course teaching, the application of multimedia technology should make full use to improve teaching efficiency. Multimedia technology can represent some contents and some abstract construction measures words are difficult to describe clearly. For example, the stress process of structure component and failure pattern are explained by Flash software demo, make parts of the plate, beam and column structure models, and introduce PPT to engineering example pictures, etc. In teaching, combine multimedia technology and traditional teaching means can be twice the result with half the effort.

Considering the strong practical characteristic of concrete structure course, in the process of teaching, case teaching should be timely applied. According to teaching objectives and requirements, use real engineering case to guide students learning, let the students understand through their observation of engineering case and analysis, guide students learn knowledge with engineering cases, and deepen students' understanding of the concepts of basic principle and concrete.

\section{Conclusion}

Concrete structure course is a very strong comprehensive professional course, and has strong engineering practicality. The improvement of concrete structure course teaching quality is imperative in teaching reform. The above organic integration of concrete structure course contents and good combination of structural earthquake knowledge may play an active push for cultivating civil engineering professional and technical personnel.

\section{Reference}

[1]Liu Yan, Thinking on building structure teaching of architecture Specialty[J], Journal of Architectural Education in Institutions of Higher Learning,2011（in Chinese）,20(4),P89-91.

[2] PAN Ying, Thinking on teaching quality improvement of concrete structural fundamentals course[J]. Journal of Architectural Education in Institutions of Higher Learning,2011 ( in Chinese), 20(4),P74-77.

[3]National Professional Guidance Committee of High School Civil Engineering, Guiding Professional Regulation for the Undergraduate Course of Higher School Civil Engineering[S]. China Architecture \& Building Press, 2011 (in Chinese).

[4]LIN Feng, GU Xiang-lin, He Min-juan. Characteristics of modern civil engineering and undergraduate program of civil engineering specialty[J]. Journal of Architectural Education in Institutions of Higher Learning,2006(15) （in Chinese）.1: P26-28

[5] National Standard of the People Republic of China, Code for design of concrete structures (GB50010-2010) [S]. China Architecture \& Building Press, 2011（in Chinese) 